\title{
Possibilities of Using Dam Reservoir Sediments in
}

\section{Earthworks}

\author{
Karolina Kos \\ Department of Hydraulic Engineering and Geotechnics, Faculty of Environmental Engineering and Land Surveying, University of \\ Agriculture, Cracow 30-059, Poland
}

\begin{abstract}
A possibility of using bottom sediments from dam reservoir as a material for earthen embankments was considered in the paper. It was stated that sediments cannot be used for road or hydrotechnical embankments without improving their geotechnical parameters. Thanks to low values of the permeability coefficient, they can be used for sealing elements in embankments or for low levees. In order to verify usability of this material for mentioned levees, stability and filtration calculations were carried out using Finite Element Method (FEM) analysis. It was stated the levee built from bottom sediments is stable even at the height of $8.0 \mathrm{~m}$, despite the boundary conditions on the upstream side.
\end{abstract}

Key words: Dam reservoirs, dredging, stability.

\section{Introduction}

As a result of the siltation process, the bed load, which is transported by the tributaries, is deposited within dam reservoirs. This process has many negative results and it can make functioning and exploitation of the reservoir more difficult. One of the methods used to restore the retention capacity which was lost due to the siltation is dredging. In most cases, it is impossible to use excavators to remove the sediments on a completely empty reservoir, then, a dredger cutter can be used, which transports the pulp by pipelines out of the reservoir. Using bottom sediments in this liquid form is inconvenient, because sludge drying beds as well as a specific period of time for sediments drying are required. This process could be made more efficient by using different types of geosynthetics tubes, where the dredged pulp is drained. Conditioned pulp is put in dewatering tubes, which are sewn from geosynthethic that keeps the particles inside and at the same time, allows water to drain (Fig. 1). Sediments dredged from dam reservoirs can be used in many ways - as an addition to soils to improve

Corresponding author: Karolina Kos, Ph.D., main research field: soil mechanics. E-mail: karolinasudyka@wp.pl. their fertility, as a material used to level the ground or build up reservoirs slopes and earth embankments [1-3]. In 2001, a project of land reclamation of Roznowskie lake (southern Poland) was prepared to deepen the reservoir, eliminate shallows and elevate the lakeside using dredged material. The concept of this project was to balance the amount of soil dredged from the reservoir with the amount needed to elevate the shoreline [1]. Despite this example in most cases, the sediments are put on a heap or they are used in leveling the areas around the reservoir. Meanwhile, using bottom sediments from dam reservoirs in earthworks can be beneficial both in terms of ecology and economy. This paper presents the analysis of possibilities of using material dredged from reservoirs as a construction material in earthen levees.

Bottom sediments from the Rzeszowski lake (southern Poland) were chosen as research material. The Rzeszow Barrage was built in 1973 in $63.7 \mathrm{~km}$ of Wislok river. The reservoir created upstream was supposed to ensure proper functioning of water intakes for the city of Rzeszow, flood protection and recreation. Initially, the capacity of the reservoir was 1.8 million $\mathrm{m}^{3}$ and the surface area was $682,000 \mathrm{~m}^{2}$ [4]. Total 


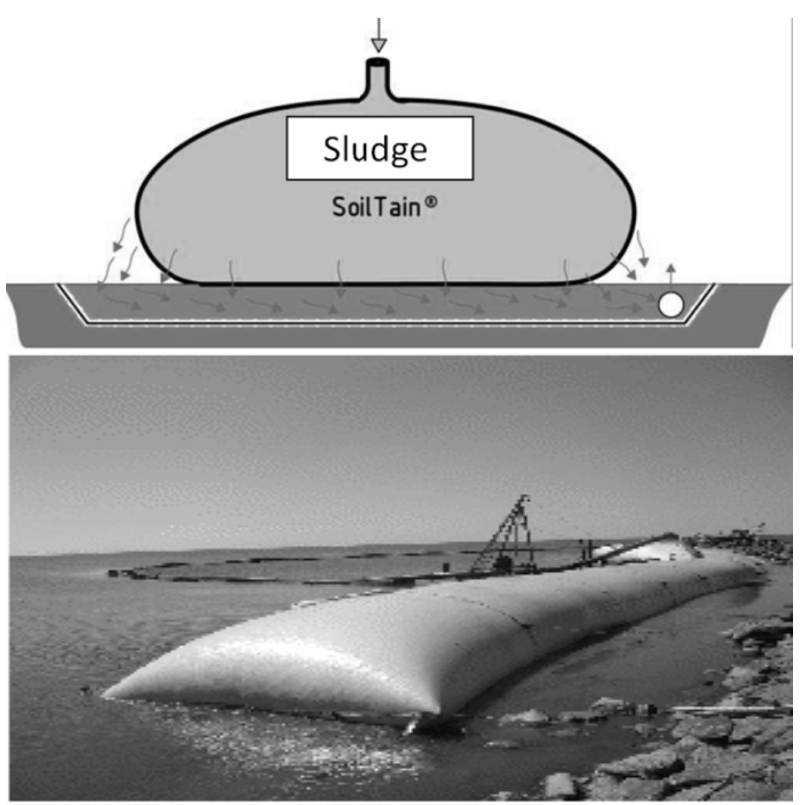

Fig. 1 Geotube soiltain [7].

water catchment area of Wisłok river is over 3.5 thousand $\mathrm{km}^{2}$, while the partial catchment area of the reservoir is over $2,060 \mathrm{~km}^{2}$, so, it is over $58 \%$. Source of Wislok is in the area classified as mountain and submontane. In the catchment area, there are different types of soils: mostly brown, silty soils with low permeability, heavy clays and clayey silts [5]. Siltation process was very intense in Rzeszowski lake. Currently, over $60 \%$ of its original capacity is filled with sediments and therefore, the reservoir does not fulfill its functions any more. It is estimated that about 1.5 million $\mathrm{m}^{3}$ of sediments could be dredged from the reservoir [6].

\section{Materials}

A detailed description of each taken sample of the sediments can be found in author's paper [8]. Bottom sediments of Rzeszowski lake were classified as silts, with very low permeability, elevated organic matter content and high compressibility (primary oedometric modulus was $3.86 \mathrm{MPa}$ ). At optimal moisture content and high compaction $\left(\mathrm{C}_{\mathrm{R}}=100 \%\right)$ shear strength parameters were relatively high (the angle of internal friction increased from $23^{\circ}$ up to almost $34^{\circ}$ and cohesion from $33 \mathrm{KPa}$ to about $36 \mathrm{KPa}$ along with increase of compaction index from 0.90 to 1.00 , these parameters were determined in shear box apparatus).

Preliminary usability evaluation was carried out based on general recommendations of Polish standard [9] on earthworks (Table 1). Tested sediments fulfill criteria concerning clay fraction content, uniformity coefficient and liquid limit set for low layers of embankments. Only the value of maximum dry density is too low. According to this standard, it is recommended to use non-cohesive frost resistant soils up to freezing depth and doubtful soils only when the water conditions are good. Based on frost heave susceptibility criteria [10], bottom sediments from Rzeszowski lake are classified as frost heave susceptible. Therefore, they can be used only below the freezing depth which practically makes it impossible to use in embankments without special actions which would improve their parameters.

\subsection{Road Embankments}

Usability of soils in road engineering is set by the standard [11], which gives specific requirements set for materials used in road embankments. They concern granulation, frost heave susceptibility, compaction parameters, consistency, organic matter content and

Table 1 Geotechnical parameters of dredged material in relation to the requirements set for soils used in earthen embankments [9].

\begin{tabular}{|c|c|c|c|}
\hline Parameter & & Requirements & Parameters of the dredged material \\
\hline Maximum dimension of a grain $(\mathrm{mm})$ & & 200 & There are no grains $>200 \mathrm{~m}$ \\
\hline Clay fraction content $(\%)$ & & $<30$ & 8.5 \\
\hline Uniformity coefficient, $\mathrm{CU}$ & & $\geq 3$ & 13.3 \\
\hline Maximum dry density $\left(\mathrm{g} \cdot \mathrm{cm}^{-3}\right)$ & & $\geq 1,6$ & 1.445 \\
\hline $\begin{array}{l}\text { Liquid limit }(\%) \\
\text { (depending on the layer) }\end{array}$ & $\begin{array}{l}\text { top } \\
\text { down }\end{array}$ & $\begin{array}{l}<35 \\
<65\end{array}$ & 40.6 \\
\hline
\end{tabular}


bearing capacity. Mentioned standard classifies silts (testes dredged material) as useful for bottom layers of an embankment provided that they are dry or protected from surface and ground waters. It also allows to use this type of material for top layers in a freezing zone, provided that it will be improved with binding agents like cement, lime or ash.

Geotechnical parameters of the material dredged from Rzeszowski lake are rather poor, mainly because of increased organic matter content, high liquid limit and frost heave susceptibility. Tested sediments do not fulfill most of the given criteria, therefore, they cannot be used as a construction material in road embankments (Table 2).

\subsection{Levees}

Tested dredged material fulfills some criteria set for the soils used to build levees (Table 3), in particular, concerns permeability coefficient. The value of uniformity coefficient is too low in relation to the recommended one. Additionally, sediments do not fulfill the granulation criterion-fine fractions content is too high, whereas, content of fractions above 0.1 $\mathrm{mm}$ is too low. It can be stated that the other two criteria are fulfilled - the organic matter content is insignificantly higher than the allowable value and the angle of internal friction is close to the required limit $\left(24.3^{\circ}\right.$ in relation to the required $\left.25^{\circ}\right)$. Usability evaluation clearly indicates that the dredged material cannot be used in levees without improving their geotechnical parameters.

\subsection{Low Levees and Dikes (Class III and IV)}

In dam or levees construction, like in other earthen constructions, it is highly desired to use mostly soils available on the site. Because of high transport costs, sometimes material dredged from rivers or channels is used to build levees, dikes and other low embankments. These materials are usually organic soils, which should not be used according to

Table 2 Geotechnical parameters of dredged material in relation to the requirements set for soils used in road embankments [11].

\begin{tabular}{|c|c|c|c|}
\hline Parameter & & Requirements & Parameters of the dredged material \\
\hline Maximum dimension of a grain $(\mathrm{mm})$ & & 200 & There are no grains $>200 \mathrm{~m}$ \\
\hline Uniformity coefficient, CU & & $\geq 3$ & 13.3 \\
\hline Organic matter content $(\%)$ & & $<2$ & 3.33 \\
\hline Maximum dry density $\left(\mathrm{g} \cdot \mathrm{cm}^{-3}\right)$ & & $\geq 1.6$ & 1.445 \\
\hline $\begin{array}{l}\text { Liquid limit (\%) } \\
\text { (depending on the layer) }\end{array}$ & $\begin{array}{l}\text { top } \\
\text { down }\end{array}$ & $\begin{array}{l}<35 \\
<60\end{array}$ & 40.6 \\
\hline $\begin{array}{l}\text { Fraction content }(\%) \text { : } \\
\leq 0.075 \mathrm{~mm} \\
\leq 0.02 \mathrm{~mm} \\
\text { Passive capillarity }(\mathrm{m})\end{array}$ & & $\begin{array}{l}<15 \\
<3 \\
<1.0\end{array}$ & $\begin{array}{c}95.0 \\
48.0 \\
1.37\end{array}$ \\
\hline Frost susceptibility & & - & Frost susceptible \\
\hline Bearing ratio, CBR (\%) & & $\geq 10$ & 3.2 \\
\hline
\end{tabular}

Table 3 Geotechnical parameters of dredged material in relation to the requirements set for soils used in levees [12-14].

\begin{tabular}{llc}
\hline Parameter & Requirements & Parameters for the dredged material \\
\hline Uniformity coefficient, $\mathrm{CU}$ & $>60$ & 13.3 \\
Fraction content $(\%): \geq 0.1 \mathrm{~mm}$ & $>40$ & 4.0 \\
Fraction content $(\%): \leq 0.01 \mathrm{~mm}$ & $6-20$ & 30.0 \\
Organic matter content $(\%)$ & $<2 / 3$ & 3.33 \\
Permeability coefficient, $\mathrm{k}_{10}\left(\mathrm{~m} \cdot \mathrm{s}^{-1}\right)$ & $<10^{-6}$ & $1.05 \times 10^{-8}\left(\mathrm{I}_{\mathrm{s}}=0.90\right)$ \\
Angle of internal friction, $\varphi\left({ }^{\circ}\right)$ & $>25$ & $1.12 \times 10^{-9}\left(\mathrm{I}_{\mathrm{s}}=1.00\right)$ \\
(saturated and undrained) & & $24.3\left(\mathrm{I}_{\mathrm{s}}=0.95\right)$ \\
\hline
\end{tabular}


geotechnical standards. Although in Poland, there are many kilometers of levees built using local organic soils which fulfill their function $[15,16]$. This proves that river or reservoir sediments, despite all the concerns for using them, can be successfully used as a material in earthen constructions, especially those which are ranked in class III or IV (low height, sudden failure of the levee would not result in any major damages or loss of human life). Using organic soils in embankments is particularly justified in case of weak ground, because organic soils levees are much lighter than mineral ones. Being examples of using organic soils in earthworks, the following can be mentioned:

- Many kilometers of fishponds dikes, levees or side dams in the north-eastern Poland, in Pomorze, the Notec river valley $[15,16]$. The levees were built from local organic soils, alluvia (from channels and ditches), gytia and peats;

- In the southern Poland-dikes around the sedimentation tanks in Jaworzyna Slaska [17]. River alluvial soils, classifies as sandy silt with organic matter content from $3.5 \%$ to $4.9 \%$, maximum dry density of $1.56-1.68 \mathrm{~g} \cdot \mathrm{cm}^{-3}$, angle of internal friction $12 / 15^{\circ}$ and cohesion 12-15 KPa were used. Mentioned parameters were relatively high, so, required compaction and stability were easily obtained for a 2.5 $\mathrm{m}$ dike;

- Test dikes build in Rostock and Gdansk under the Dredg Dikes project [18] - the EU project Dredg Dikes is a South Baltic Cross-border Co-operation Project, dealing with the implementation of dredged materials in dike construction, it includes building test dikes from dredged materials, so far, field experiments show positive results.

These examples prove that dam reservoir sediments, as organic soils, can be successfully used to build low earthen levees. Although, it should be remembered that protection from degradation is a crucial issue in case of using organic soils in embankments. Organic levees degrade much more than levees from mineral soils, both when it comes to time and extent, which is mainly related to rotting. Rotting process is a result of drainage and airing of soil, which was constantly saturated before building in. Many factors influence this process-physical (shrinkage and swelling), biochemical (secondary humification and mineralization) and weather conditions (freezing, wind and sun) [15]. The mentioned author states that in order to lower the intensity of degradation, the following actions can be done:

- protection of moisture by covering the soil with a layer of mineral soil and grass;

- reducing the amount of air in soil by its proper compaction;

- reducing the amount of organic matter content by using mixtures of organic and minerals soils.

Based on the carried out analysis of technical condition and safety of levees made from organic sediments in Zulawy Wislane Borys and Rycharska [16], it stated that although they were highly heterogeneous and the compaction was insufficient, the levees were stable and a threat to the safety of this type of levees could be connected with filtration processes (increase in permeability due to degradation). The authors emphasized a good condition of levees that had been modernized 10 years before through dynamic compaction of the existing levee and its elevation and widening, since there were no signs of alarming filtration phenomena.

Based on the mentioned examples from the literature, it can be stated that the material dredged from Rzeszowski reservoir - that have beneficial permeability and shear strength parameters and at the same time, low organic matter content, can be used to build hydrotechnical embankments of low technical class without improving their parameters.

\section{Results and Discussion}

\subsection{Stability Analysis of Levees from Dredged Material-Methods}

Stability calculations of levees were carried out 
using Finite Element Method (FEM) in Z.SOIL.PC program [19]. An elastic-perfectly plastic Mohr Coulomb model was used to describe the behavior of soil medium [20]. The factor of safety was calculated using strength reduction method [21]. Filtration calculations were carried out for steady and unsteady seepage flow.

Stability calculations were carried out for embankments on the ground from permeable medium sands of high thickness and impermeable layer of clay below them (Fig. 2). Three variants were assumed without seepage flow and with steady and unsteady seepage flow (simulating flood wave). A one-week flood wave with 72-hours culmination was simulated. The width at the top of the embankments was $3.0 \mathrm{~m}$, inclination was $1: 2$ and height were $4.0 \mathrm{~m}, 6.0 \mathrm{~m}$ and $8.0 \mathrm{~m}$. Maximum level of water table was $1.0 \mathrm{~m}$ below the top of the levee. Geotechnical parameters of the dredged material (Table 4) are based on author's tests, whereas, the soil in the ground typical values for given soil type were assumed. Default values of the Young modulus and the Poisson ratio $(\mathrm{E}=100 \mathrm{MPa}, v$ $=0.3$ ) were assumed for each material, whereas, the dilatancy angle $\psi$ was $0^{\circ}$ or $\varphi$.

\subsection{Results}

The levee from the dredged material maintained stability regardless of its height when there was no seepage flow. The factor of safety decreased from 3.0 to 2.4 as the height of the levee increased from $4 \mathrm{~m}$ to $8 \mathrm{~m}$ (Table 5).

Stability was much worse when steady seepage (where the water level is $1.0 \mathrm{~m}$ below the top of the levee) was taken into consideration. As a result of seepage the potential slip surfaces occurred on the downstream slope (Fig. 3). The factor of safety decreased from 2.7 to 2.0 as the height of the levee increased from $4 \mathrm{~m}$ to $8 \mathrm{~m}$.

In case of the flood wave, the calculations showed that slopes maintained stability at each height of the levee. During the maximum water level (5th day), potential slip surfaces occurred on the downstream side and after drawdown (7th day), because of seepage slip surfaces with the lowest factors of safety occurred on the upstream slope (Fig. 4). Values of the factor of safety determined during the maximum water level decreased from $2.9 \mathrm{~m}$ to $2.2 \mathrm{~m}$ depending on the height of the levee. They were a little bit higher for the upstream slope, after drawdown - they decreased from $3.2 \mathrm{~m}$ to $2.6 \mathrm{~m}$ along with the increase in the height of the levee from $4 \mathrm{~m}$ to $8 \mathrm{~m}$. At each height, the highest factors of safety were calculated when there were no water on the upstream side, whereas, the lowest, as expected, with steady seepage flow.

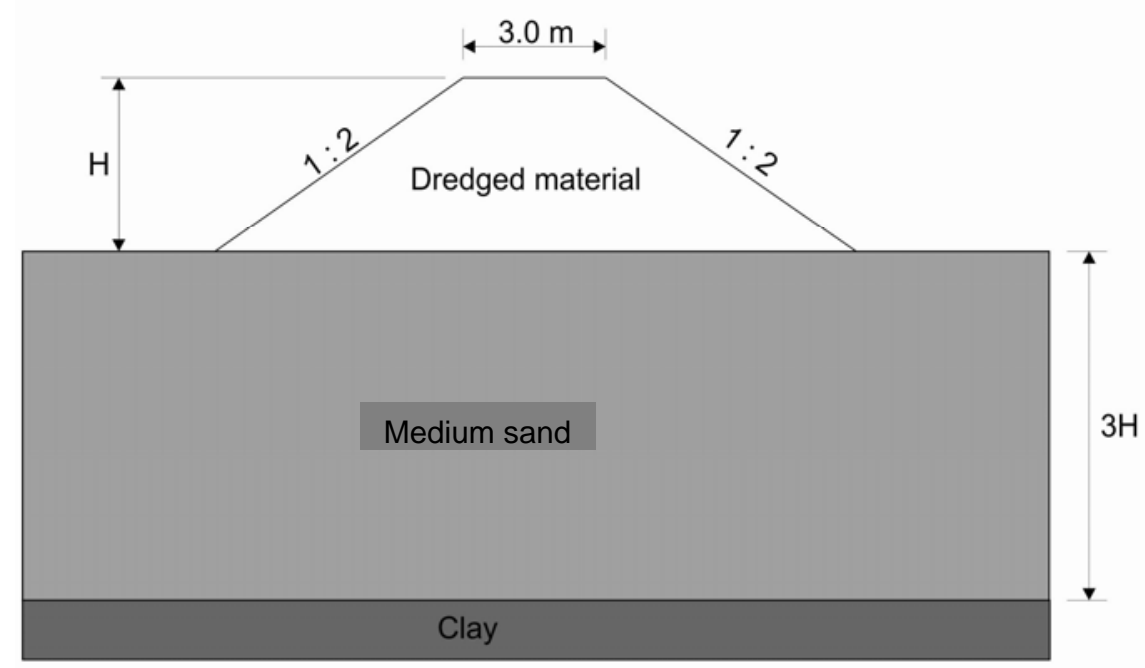

Fig. 2 Cross-section of the analysed levee. 
Table 4 Geotechnical parameters of the dredged material and soils used in stability calculations.

\begin{tabular}{llll}
\hline \multirow{2}{*}{ Parameter } & Material & & \\
\cline { 2 - 4 } & Dredged material—silt $\mathrm{I}_{\mathrm{s}}=0.90$ & $\begin{array}{l}\text { Medium sand } \\
\mathrm{I}_{\mathrm{D}}=0.80\end{array}$ & $\begin{array}{l}\text { Clay } \\
\mathrm{I}_{\mathrm{L}}=0.20\end{array}$ \\
\hline Angle of internal friction, $\varphi\left(^{\circ}\right)$ & 23.1 & 35.0 & 18.0 \\
Cohesion, $\mathrm{c}(\mathrm{kPa})$ & 33.1 & 0 & 30.0 \\
Unit weight, $\gamma\left(\mathrm{kN} \cdot \mathrm{m}^{-3}\right)$ & 20.1 & 18.6 & 21.0 \\
Permeability coefficient, $\mathrm{k}_{10}\left(\mathrm{~m} \cdot \mathrm{s}^{-1}\right)$ & $1.05 \times 10^{-8}$ & $1.0 \times 10^{-4}$ & $1.0 \times 10^{-10}$ \\
Porosity index, $\mathrm{e}(-)$ & 0.843 & 0.565 & 0.242 \\
\hline
\end{tabular}

Table 5 Stability calculations results.

\begin{tabular}{|c|c|c|c|c|}
\hline \multirow{2}{*}{\multicolumn{2}{|c|}{ Boundary conditions on the upstream side }} & \multicolumn{3}{|c|}{ Factor of safety FS (-) at the height of a levee } \\
\hline & & $4.0 \mathrm{~m}$ & $6.0 \mathrm{~m}$ & $8.0 \mathrm{~m}$ \\
\hline \multicolumn{2}{|c|}{ No seepage-levee after construction } & 3.06 & 2.64 & 2.39 \\
\hline \multicolumn{2}{|c|}{ Steady seepage-water level $1.0 \mathrm{~m}$ below the top of the levee } & 2.68 & 2.32 & 2.08 \\
\hline \multirow{2}{*}{$\begin{array}{l}\text { Unsteady seepage } \\
\text { flow-flood wave simulation }\end{array}$} & maximum water level ( 5 th day) & 2.86 & 2.52 & 2.23 \\
\hline & after drawdown (7th day) & 3.17 & 2.89 & 2.60 \\
\hline
\end{tabular}

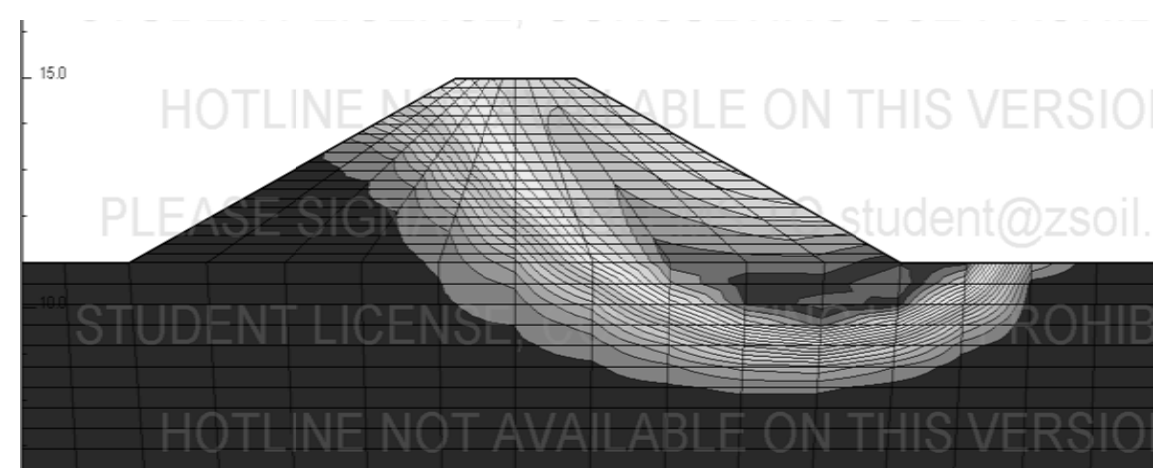

Fig. 3 Displacement amplitude isolines for a levee $4.0 \mathrm{~m}$ high at the steady seepage flow.

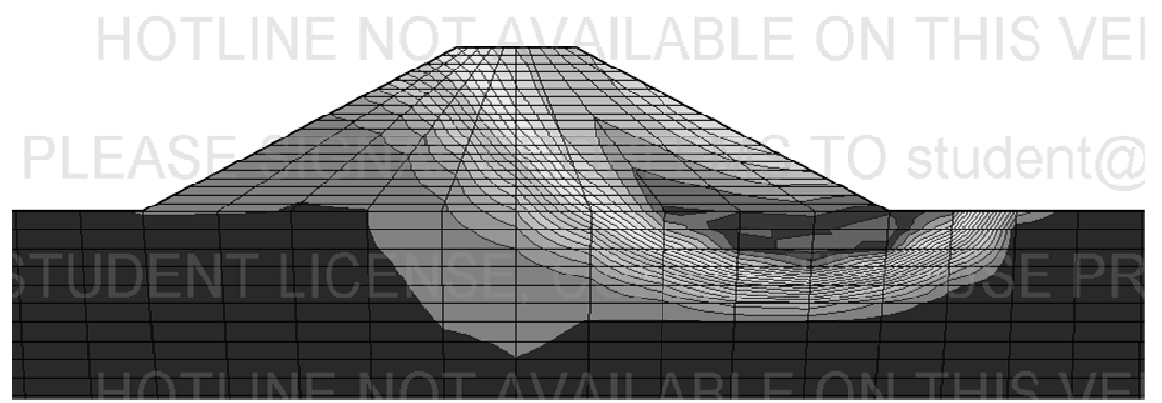

(a)

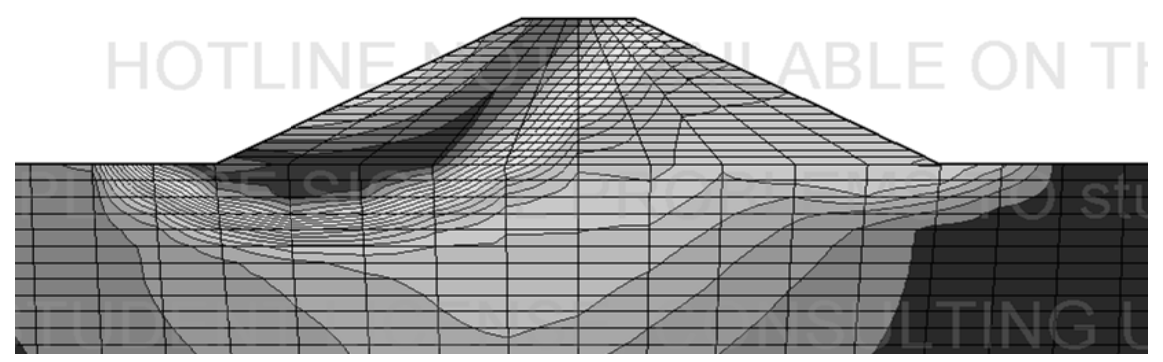

(b)

Fig. 4 Results of the slope stability calculations for the unsteady seepage flow: at maximum water level (a) and after drawdown (b) (levee $4.0 \mathrm{~m}$ high). 


\section{Conclusions}

Siltation is a process that occurs in every dam reservoir, it involves sedimentation of the bed lad transported by its tributaries. If the quantity of sediments in the reservoir considerably influences its functioning, the solution is often dredging. One of the reservoirs where the siltation process was very intense and caused limitation of its usability is Rzeszowski lake. If the dredging was carried out, it is estimated that over 1.5 million $\mathrm{m}^{3}$ of sediments could be taken out, then, there would be a problem with disposal of the dredged material. If it was used in earthworks, it would be of great ecological importance-instead of putting it on a heap, for example, the sediments would be used to build embankments.

Based on the carried out usability evaluation, it was stated that material dredged from Rzeszowski Reservoir, because of elevated organic matter content and frost heave susceptibility, cannot be used in road engineering. Although, thanks to beneficial value of the permeability coefficient and shear strength, these sediments can be used as a material for levees of lower technical classes.

In order to verify usability of this material for levees, multiple stability and filtration calculations for a levee built from the sediments were carried out. Calculations using FEM method in a Z.SOIL.PC program showed that the levee, whose slopes had an inclination 1:2, built on the ground from permeable soils, was stable until the height of $8.0 \mathrm{~m}$, regardless of the water level on the upstream side. Factor of safety values were high and above 2.0. Because of seepage force, the lowest values were calculated with steady seepage flow through the levee (constant damming).

Analysis and calculations presented in the paper allowed to determine if there is a possibility of using dredged material from Rzeszowski lake in earthworks. So, it can be used in a sustainable way. Thanks to that the bottom sediments can be used in earthworks instead of natural soils, whose reserves are limited and not nonrenewable.

\section{References}

[1] Dymkowski, A., and Lewandowski, R. 2001. "Reclamation of Chosen Banks and Dredging in Roznow and Czchow Reservoirs." Gospodarka Wodna 10: 420-423.

[2] Gwozdz, R. 2007. "Properties of Cohesive Sediments from Roznowskie Lake in the Aspect of Their Usage in Earthworks." Doctoral thesis, Cracow University of Technology.

[3] Madeyski, M., and Bednarz, J. 2004. "Using Bottom Sediments from a Chosen Water Reservoir." Scientific Papers of Environmental Engineering 25: 283-292.

[4] The Regional Water Management Authority in Cracow. 2010. "Rzeszow Barrage." Accessed May 20, 2010. http://www.krakow.rzgw.gov.pl.html.

[5] Madeyski, M., Michalec, B., and Tarnawski, M. 2008. "Siltation of Small Water Reservoirs and the Quality of the Sediments." Infrastructure and Ecology of Rural Areas 11: 15-17.

[6] Kos, K., and Zawisza, E. 2015. "Stabilization of Bottom Sediments from Rzeszowski Reservoir." Annals of Warsaw University of Life Sciences-SGGW Land Reclamation 47 (2): 127-137

[7] INORA Company. 2014. "Fast, Effective and Economic Method of Draining Bottom Sediments." Accessed January 10, 2014. http://www.odwadnianie-osadow.pl/ artykuly-i-publikacje.html.

[8] Kos, K., and Zawisza, E. 2015. "Geotechnical Characteristics of the Bottom Sediments from Rzeszowski Reservoir." Journal of Civil Engineering, Environment and Architecture 62 (3): 45-56.

[9] PN-B-06050. 1999. Geotechnics, Earthworks and General Requirements. Polish Standard. Warsaw: Polish Normalization Committee.

[10] Catalogue of Typical Flexible and Semi-rigid Pavement Structures. 1997. General Directory for National Roads and Motorways. Warsaw: IBDiM.

[11] PN-S-02205. 1998. Roads. Earthworks, Requirements and Tests, Polish standard. Warsaw: Polish Normalization Committee.

[12] Jarocki, W. 1963. Water Engineering, Part II. Warsaw: State Publishing House for Agriculture and Forestry.

[13] Sobczak, J. 1975. Dams from Local Materials. Warsaw: Polish Scintific Publishers.

[14] PN-B-12095. 1997. Water-Meliorative Devices, Levees, Requirements and Tests, Polish Standard. Warsaw: Polish Normalization Committee. 
[15] Borys, M. 1993. Low Levees from Local Organic Soils. Falenty: The Institute for Land Reclamation and Grassland Farming.

[16] Borys, M., and Rycharska, J. 2004. "Evaluation of the Technical Condition of Levees from Organic Silts on the Example of Zulawy Elbląskie." Water-Environment-Rural Areas 4 (12): 319-334.

[17] Traczyk, R. 1990. "Using River Alluvium to Build Embankments." In Materials of the 9th National Conference on Soil Mechanics and Foundations, 11-13.
[18] South Baltic Programme. 2015. "Dredged Materials in Dike Construction." Accessed April 8, 2015. http://www.dredgdikes.eu/eu.html.

[19] Z_SOIL.PC. 1998. Theoretical Manual. Lozanna: ZACE Services Ltd..

[20] Wiłun, Z. 2000. Geotechnics. Warsaw: Transport and Communication Publishers.

[21] Truty, A. 2002. "On Certain Classes of Mixed and Stabilized Mixed Finite Element Formulations for Single and Two-Phase Geomaterials." Scientific Papers of Environmental Engineering 48: 3-26. 